To cite: M Swart \& S Hassen 'A comparison between the position of child marriage 'victims' and child soldiers: Towards a nuanced approach' (2016) 16 African Human Rights Law Journal 458-475

http://dx.doi.org/10.17159/1996-2096/2016/v16n2a7

\title{
A comparison between the position of child marriage 'victims' and child soldiers: Towards a nuanced approach
}

\author{
Mia Swart* \\ Professor of International Law, University of Johannesburg, South Africa
}

Sabreen Hassen**

Assistant Lecturer, University of Johannesburg, South Africa

\section{Summary}

This article aims to juxtapose and draw analogies between the legal position of children affected by child marriage and child soldiers. It is argued that childhood is not an undifferentiated status or category. We do not subscribe to a catch-all approach with regard to the accountability of children or those who exploit children. It is vital to make distinctions according to the age and maturity of a child, whether in the context of child soldiering or child marriage. This is the practice in most domestic legal systems and has to a large extent been followed in international instruments. This approach might seem to diverge from the so-called 'straight 18 approach' in favour of standardisation of the minimum age at which children can enter into the armed forces or enter into marriage. In our view, the 'standardisation' approach should only be followed with regard to setting the age for the definition of children at 18 years. Within the category 'children', however, we support a sliding scale approach in dealing with child soldiers and children in early marriage, an approach which will vary according to factors such as the maturity of the child, the cultural context, domestic laws and legal criteria such as voluntariness.

\footnotetext{
* $\quad$ BA (UNISA) LLB (Cape Town) LLM (Humboldt) PhD (Leiden); mswart@uj.ac.za. An earlier version of this article was presented at the 'Ending the Scourge of Child Marriage in Africa' conference, Lusaka, Zambia, October 2015.

** LLB LLM (Johannesburg); shassen@uj.ac.za
} 
Whereas we emphasise that children under the age of seven do not possess criminal capacity and do not have the ability to give genuine consent to marriage, the position of children over the age of seven is more complex. We argue that children on the verge of adulthood should not be stigmatised for voluntarily entering into marriage.

Key words: child soldiers; child marriage; accountability; criminal capacity

\section{Introduction}

The question whether and to what extent children should be held accountable for international crimes is a difficult issue in international law. According to conventional wisdom, children are mostly innocent and passive victims that should be protected from criminal prosecution. This view is also held by the majority of scholars, and is described as a 'protectionist' approach. The innocent victim perception has a strong hold on what Drumbl calls the 'international legal imagination'. ${ }^{1}$ This perception affects the way in which children affected by child marriage as well as child soldiers are viewed.

The article aims to both juxtapose and draw analogies between the legal position of children affected by child marriage and child soldiers. It will be argued that childhood is not an undifferentiated status or category. Therefore, we do not subscribe to a catch-all approach with regard to the accountability of children or those who exploit children. It is vital to make distinctions according to the age and maturity of a child, whether in the context of child soldiering or child marriage. This is the practice in domestic law and has to a large extent been followed in international instruments. This approach might seem to diverge from the so-called 'straight 18 approach' $^{2}$ in favour of standardisation of the minimum age at which children can enter into the armed forces or enter into marriage. In our view, the 'standardisation' approach should only be followed with regard to setting the age for the definition of children at 18 years. Within the category 'children', however, we support a sliding scale approach in dealing with child soldiers and children in early marriage, an approach which will vary according to factors such as the maturity of the child, the cultural context, domestic laws and legal criteria such as voluntariness. Whereas we emphasise that children under the age of seven do not possess criminal capacity and do not have the ability to give genuine consent to marriage, the position of children over the age of seven is more complex. We argue that children on the verge of

1 Drumbl describes the international legal imagination as a 'normative, aspirational and operational mix of international law, policy and practice'; M Drumbl Re-imagining child soldiers (2012) 9.

2 See Child Soldiers International, http://www.child-soldiers.org/theme_reader. php?id=1/ (accessed 20 September 2016). 
adulthood should not be stigmatised for voluntarily entering into marriage.

The article, therefore, aims to take a more nuanced approach than approaches which generalise about children. A distinction will be made between early childhood, adolescents and children on the verge of young adulthood. It will be argued that, since children as young as 14 years are deemed to have criminal capacity in many domestic legal systems, ${ }^{3}$ mature children should not necessarily escape accountability for their crimes. Although legal systems vary in terms of the age at which they consider children to have criminal capacity, ${ }^{4}$ it will be argued that the correct approach is one that takes a more nuanced view of the category 'childhood'.

Furthermore, article 4(3)(c) of Additional Protocol II to the Geneva Conventions prohibits the recruitment and use of children under the age of 15 to take part in hostilities. This means that there is a window period (between 15 and 18 years) during which children could be deemed to have the criminal capacity, agency and autonomy to decide voluntarily to enter into hostilities. It follows from the voluntary nature of such acts that children expose themselves to the risk of criminal prosecution. It will be submitted that, although the authors do not support criminal prosecution in all cases of atrocities committed by and to children and would mostly find alternative accountability mechanisms more appropriate, it would be appropriate in certain limited circumstances to hold children accountable where it can be proven that children between the ages of 15 and 18 years have acted voluntarily. ${ }^{5}$ However, the article does not focus on the question of whether children should be held accountable in the form of criminal prosecutions. The concept of voluntariness in the context of children will be examined as will the concept of duress.

Whereas Drumbl recognises that the term 'child soldier' is sufficiently capacious to be employed to refer to children who are soldiers outside the context of an armed conflict, the article focuses on the position of children in atrocity-producing armed conflicts, including national and international armed conflicts. These are the types of conflicts in which the question of prosecuting children or those who mistreat children is most acute. The jurisprudence of the ad hoc international criminal tribunals, the International Criminal Court and the Special Court for Sierra Leone (SCSL) with regard to child soldiers will be considered.

3 Notably, in South Africa and Germany. The age at which children have criminal capacity in France is 13. In England and Wales, the age is even younger. Section 16 of the Children and Young Persons Act 1963 states that the age of criminal responsibility in England and Wales is ten years.

4 In North Carolina, eg, children have criminal capacity from the age of six. In other jurisdictions, such as Brazil, children have criminal capacity from age 18 . For this data, see Drumbl (n 2 above) 104.

5

Drumbl (n 1 above) 11 . 


\section{Definition of 'child'}

The European Convention on Human Rights, the American Declaration on the Rights and Duties of Man, the International Convention on the Elimination of All Forms of Racial Discrimination (CERD), the Convention on the Rights of the Child (CRC), the African Charter on Human and Peoples' Rights (African Charter) and the ILO Worst Forms of Child Labour Convention all make mention of the term 'child' several times. A 'child' is defined as being 'every human being below the age of eighteen years of age' by the CRC, ${ }^{6}$ the African Charter on the Rights and Welfare of the Child (African Children's Charter $)^{7}$ and the ILO Worst Forms of Child Labour Convention. ${ }^{8}$ This definition centres on the objective element of age.

Whereas there is broad agreement in international law on the age at which individuals are considered 'children', namely, 18 years, there is less agreement on the question of the age at which individuals can participate in conflict.

A few key international instruments consider the age of 15 years as significant. Of these provisions, article 38 of the CRC is the most significant. In terms of article 38, the minimum age for recruitment or participation in armed conflict is the lower age of 15 . The wording is taken from article 77(2) of Additional Protocol I to the 1949 Geneva Conventions.

The Rome Statute of the International Criminal Court is arguably the most important current instrument guiding international criminal law. The definition of war crimes in the Rome Statute includes 'conscripting or enlisting children under the age of fifteen years into national armed forces or using them to participate actively in hostilities' ${ }^{\prime 9}$ in international armed conflict. As far as internal armed conflict is concerned, the Statute states that 'conscripting or enlisting children under the age of fifteen years into armed forces or groups or using them to participate actively in hostilities' is prohibited. ${ }^{\text {To }}$

Sexual slavery is defined as a war crime $^{11}$ and a crime against humanity. ${ }^{12}$ As will be discussed below, sexual slavery can be a form of child soldiering, since children who are forced into sexual slavery are often associated with an armed group. The United Nations

6 Convention on the Rights of the Child, General Assembly Resolution 1386 (XIV) art 1.

7 African Charter on the Rights and Welfare of the Child (1990), OAU Doc CAB/ LEG/24.9/49 (entered into force 1999) art 2.

8 ILO Worst Forms of Child Labour Convention 182 (entered into force 19 November 2000) art 2.

9 Art $8(2)(b)(x \times v i)$.

10 Art 8(2)(e)(vii).

11 Art 8(2)(b)(xxii).

12 Art 7(1)(g). 
Children's Fund (UNICEF) has observed that children often fulfil multiple roles in conflict situations. ${ }^{13}$

Whereas the law of wars puts a general prohibition on the recruitment of child soldiers under the age of 15 years, efforts have been made by humanitarian groups to extend this ban to persons under the age of 18. The non-governmental organisation (NGO) coalition Stop the Use of Child Soldiers as well as the CRC have adopted the so-called 'straight $18^{\prime}$ position. This approach has received wide acceptance amongst states ${ }^{14}$ and is advocated in soft law instruments, such as the Paris Principles, as well as by influential international organisations, such as Amnesty International. ${ }^{15}$ However, until such time as this has been achieved, there is no agreed definition, but there is agreement that it should not be below 15 years of age.

Some states still permit the voluntary recruitment of children under the age of 18 . Fortunately, this number is diminishing. For example, 17 year-olds can enlist in the armed forces of countries such as France, Germany and Israel, ${ }^{16}$ and the number of states that continue to allow the voluntary recruitment of children at the lower age of 16 years is not insignificant. ${ }^{17}$ In a few states, there is no minimum age or the age has been set below 16 years. Such states include Barbados, Guinea Bissau, Guyana, Pakistan and the Seychelles.

The Optional Protocol argues for increased momentum towards 18 as the universal minimum age for conscription and enlistment by states' armed forces. Ultimately, it should be remembered that, like all age limits in law, setting the age limit for childhood at 18 is essentially arbitrary. Tobin asks the question: 'Does a child of 15, 16 of 17 years really need special protection relative to adults, or are their physical and mental capacities sufficiently aligned with the capacities of persons over 18 years of age $?^{\prime 18}$ The arbitrariness becomes especially clear if it is kept in mind that determining the exact age of many children is almost impossible due to the loss of birth certificates (particularly by those from refugee source countries) or the fact that births in conflict zones are often not registered.

13 'A guide to the Optional Protocol on the Involvement of Children in Armed Conflict' UNICEF Report 3.

14 Child Soldiers International (n 2 above).

15 Amnesty International 'Child soldiers: Criminals or victims?' IOR 50/002/2000 22 December 2000.

16 Countries following this approach are Australia, Austria, Algeria, Brunei, Bolivia, Cuba, Cape Verde, Chile, China, Cyprus, France, Israel, Germany, Lebanon, Jamaica, Malaysia, The Netherlands, New Zealand, the Philippines, the USA and Saudi Arabia.

17 The following countries follow this approach: Brazil, Bangladesh, Canada, Egypt, India, Iran, Ireland, Jordan, Pakistan, Singapore, Mexico, Mauritania, Papua New Guinea, Trinidad and Tobago, the United Kingdom and Zambia.

18 J Tobin 'Justifying children's rights' (2013) International Journal of Children's Rights 21. 


\section{Definition of child marriage}

According to UNICEF, child marriage is as 'a formal marriage or an informal union before age $18^{\prime} .^{19}$ The Convention on the Elimination of All Forms of Discrimination Against Women (CEDAW) states that 'the marriage of a child shall have no legal effect', thereby outlawing child marriages. ${ }^{20}$ The African Children's Charter unequivocally prohibits child marriages of both boys and girls under the age of 18 years. Even though marriage is not directly referred to in the CRC, it is frequently addressed by the CRC Committee as it is linked to other rights in the $C R C$. These rights include the right to protection from all forms of abuse 21 and the right to be protected from harmful traditional practices. ${ }^{22}$ Furthermore, the Pan-African Forum Against the Sexual Exploitation of Children regards child marriage as a kind of commercial exploitation of children, which is also prohibited in the CRC. ${ }^{23}$ Whilst child marriage also affects young boys, ${ }^{24}$ the number of girls affected is much higher. ${ }^{25}$ As a result of the impact this has on girls, it is safe to say that child marriage is a manifestation of discrimination against girls which goes against the grain of CEDAW and is clearly outlawed.

According to a UNICEF report, ${ }^{26}$ child marriage has the following consequences: first, girls are denied their childhood. Second, they are socially isolated from their friends and, more importantly, their families, while the CRC explicitly protects children from being subjected to interference with their families and homes. ${ }^{27}$ Third, they have limited employment and educational opportunities as most child brides abandon their education, which is contrary to their right to education. ${ }^{28}$ Fourth, they are not able to safely negotiate safe sex with their partners. This inability to negotiate safe sex in itself can be seen as a type of sexual abuse, which is also prohibited by the CRC. ${ }^{29}$ Fifth, many health implications, especially sexual health problems, flow from early marriage, even though the CRC protects children's rights

19 http://www.unicef.org/protection/57929_58008.html (accessed 14 September 2015).

20 Art 16.

21 Art 19.

22 Art 24(3).

23 Arts $19 \& 34$.

24 See http://www.unicef.org/protection/57929_58008.html (accessed 14 September 2015).

25 In Zambia, eg, 45\% of women between the ages of 20 and 49 were married by the age of 18. According to the Zambia Demographic and Health Survey Report, child marriage is more common among girls (17\%) than boys (1\%). 'Child marriage situation for Zambia: Qualitative and quantitive summary' (report) (2015), paper presented at National Workshop on Child Marriage Laws in Zambia, 23-24 June 2015.

26 UNICEF 'Ending child marriage: Progress and prospects' 22 July 20148.

27 Art 16.

28 Art 28 CRC.

29 Art 34. 
to health. ${ }^{30}$ Sixth, early pregnancy results in a higher mortality rate not only of the young mothers but also of their infants, indirectly infringing the right to life. ${ }^{31}$

By allowing child marriages, a state does not only violate the CRC and CEDAW, but also the Universal Declaration of Human Rights, a declaration that is widely considered to have become hard law. The Universal Declaration guarantees the right to free and full consent to marriage. It is clearly not possible for consent to be free and full if one party to the marriage is not sufficiently mature to make an informed decision regarding the choice of a marriage partner. ${ }^{32}$ In the absence of free and full consent, it would follow that such a marriage is 'forced'. In The Special Court for Sierra Leone in 2008 held that forced marriage was a crime against humanity. ${ }^{33}$ Early in 2016, the Constitutional Court of Zimbabwe outlawed child marriage in the case of Mudzuru ${ }^{34}$ and raised the minimum age for marriage to 18 years. ${ }^{35}$ The judgment was based on the finding that section 78 of the Zimbabwean Constitution sets the minimum age for marriage at 18 . In this case, the Deputy Chief Justice of Zimbabwe referred to article 16(2) of CEDAW according to which only women and men of full age can marry.

In order to meet the requirements of a crime against humanity, an act must be part of a 'widespread and systematic attack'. The International Criminal Tribunal for Rwanda (ICTR) in Akayesu defined 'widespread' as 'massive frequent large-scale action, carried out collectively with considerable seriousness and directed against a multiplicity of victims'. ${ }^{36}$ The brief list of consequences flowing from child marriage mentioned above satisfies the 'considerable seriousness' criterion. The 'multiplicity' requirement is probably the easiest requirement to satisfy because, according the International Research Centre for Women (IRCW), the number of women who married before they reached the age of 18 years exceeds 700 million. ${ }^{37}$

A trial chamber of the ICTR defined 'systematic' as 'thoroughly organised and following a regular pattern on the basis of a common policy'. ${ }^{38}$ The ICTR further stated that the action does not necessarily have to be official state policy; a preconceived plan or some kind of

30 Art 3(1).

31 Art 6 CRC.

32 UNICEF 'Early marriage: A harmful traditional practice' 1.

33 MP Scharf 'Forced marriage as a separate crime' in C Jalloh The Sierra Leone Special Court and its legacy (2014) 193.

34 Mudzuru \& Another $v$ The Minister of Justice, Legal Parliamentary Affairs \& 2 Others CCZ 12/2015.

35 Emma Batha 'Zimbabwe court bans child marriage' Reuters http:// www.reuters.com/article/us-zimbabwe-childmarriage-idUSKCNOUY27H (accessed 20 September 2016).

36 Prosecutor $v$ Akayesu ICTR-96-4-T para 580.

37 UNICEF (n 26 above) 8.

38 Akayesu (n 36 above ) para 580. 
policy will suffice. ${ }^{39}$ It is essential to understand that child marriage, or early marriage, is a deeply-entrenched cultural practice. This means that it may be argued that such cultural practice, which often goes unchallenged by the state, qualifies as a 'policy'. Governments also often have an interest in perpetuating the continuation of oppressive practices, such as child marriage.

Child marriage is often described as a cultural practice. As such, child marriage is heavily influenced by Islam, which is widely practised in Northern Africa, a region with a particularly high rate of child marriage. ${ }^{40}$ In countries with a high child marriage rate, cultural and social practices often hold more value in the community than laws, resulting in the poor enforcement of domestic laws prohibiting these marriages. ${ }^{41}$ Nigeria is a perfect example. Despite the fact that Nigeria has ratified the African Children's Charter as well as the CRC and has also domesticated the CRC in the Child Rights Act, ${ }^{42}$ the provisions of Shari'a (Islamic) law is more highly respected among the local population. ${ }^{43}$ While international law caps childhood at 18 years, Shari'a law specifies no maximum age for childhood. ${ }^{44}$ Under this law, maturity is determined by puberty, more particularly menstruation. 45 This, in turn, leads to the interpretation by some that a child is fit for marriage after she has reached maturity.

\section{Cultural relativity}

Since child marriage and child soldiering may be described as cultural practices and find different levels of acceptance in different contexts, it is necessary to engage with the question of whether these two practices are necessarily immoral or contrary to human rights.

At the other end of the spectrum, universality entails that the validity of rights cannot be determined with reference to culture. ${ }^{46}$ While the wide and almost unanimous support of the Universal Declaration may be seen as an acceptance of the universal approach over cultural relativism, it must be borne in mind that the Universal Declaration itself guarantees the right to cultural freedom. ${ }^{47}$ The text

39 As above.

40 UNICEF (n 32 above) 3.

41 C Burris 'Why domestic institutions are failing child brides: A comparative analysis of India's and the United States' legal approaches to the institution of child marriage' (2015) Tulane Journal of International and Comparative Law 153.

42 Child Rights Act, 2003.

43 TS Braimah 'Child marriage in Northern Nigeria: Section 61 of Part I of the 1999 Constitution and the protection of children against child marriage' (2014) 14 African Human Rights Law Journal 474.

44 Braimah (n 43 above) 481.

45 As above.

46 J Donnelly 'Cultural relativism and universal human rights' (1984) 6 Human Rights Quarterly 401.

47 Art 27(1). 
of the African Children's Charter makes it clear that the rights contained and guaranteed in the Charter are supreme over 'any custom, tradition, cultural or religious practice' inconsistent with such rights. ${ }^{48}$

Many consider the 'straight 18 ' approach to contradict established cultural and local norms. Given that international human rights law is believed to be based on universal ethical standards, ${ }^{49}$ some claim that the 'straight 18' approach does not acknowledge local and regional cultures and traditions. It is also not sensitive to varying views on the definition of a child. Therefore, some argue that an approach which is sensitive to context and to the 'the culturally-constructed' ideas and practices surrounding childhood and adulthood'50 would be more appropriate.

According to Donnelly, there are two types of cultural relativism. The first type is strong cultural relativism, which entails that the validity of a right is determined based primarily on culture. The second type, weak cultural relativism, considers culture as not being the dominant consideration in determining the validity of a right, but nevertheless an important one. ${ }^{51}$ Shari'a law may be seen as a manifestation of weak cultural relativism.

Shari'a law may be considered an example of weak cultural relativism for two reasons. First, and most importantly, Shari'a law is not the only source used in determining the validity of rights. Second, and equally important, culture and religion are separate but not mutually-exclusive concepts since the one influences the other. In the case of Shari'a law, it is Islamic law, religious law, which has a bearing and influence on culture, especially in areas where it is the predominantly practised religion. Culture, however, is influenced by a variety of different factors, including different religions, of which Islam is but one.

A crucial question is how much weight should be given to cultural relativism in this ethical debate. ${ }^{52}$ There are three possible answers. First, according to the cultural relativist theory, cultural relativism should be considered equally important as any other factor. ${ }^{53}$ This, in turn, leads to the continued tolerance of child marriage and child soldiering. A second, perhaps more acceptable, view is that some weight should, at the very least, be given to this factor. ${ }^{54}$ According to this view, the importance of the practice to the culture will

\footnotetext{
48 Art 1(3) African Children's Charter.

49 See eg BD Lepard Customary international law: A new theory with practical applications (2010).

50 Donnelly (n 46 above) 400.

51 Donnelly 401.

52 D Wilkinson 'Cultural relativism and female genital mutilation' http:// blog.practicalethics.ox.ac.uk/2014/02/cultural-relativism-and-female-genital-muti lation/ (accessed 28 September 2015).

53 Wilkinson (n 52 above).

54 As above.
} 
determine the weight ascribed to it. ${ }^{55}$ Therefore, if the practice in question lies at the roots of a culture, it should outweigh the other ethical factors. ${ }^{56}$ The last view is that cultural relativity has no place in ethical considerations and, therefore, should not be given any weight. $^{57}$

One problem with cultural relativism is that it denies the rights to women who have become aware that they have rights because they have an identity of their own separate from the community to which they belong. ${ }^{58}$ Every time a woman demands that her universallyaccepted rights be recognised, an ethical problem arises. ${ }^{59}$ When the number of demands for the recognition of women's rights increases, the ethical problem starts to take on a political nature. ${ }^{60}$ Cultural relativity is essentially a complex concept with a strong political foundation. ${ }^{61}$ However, it is perhaps naive to assert that rights which are universally accepted can and will necessarily be recognised as opposed to rules and norms that are imposed by culture. ${ }^{62}$ This is the case especially in societies where culture determines national identity or in societies where dominant social practices cannot be resisted without adverse consequences for the individual or family. ${ }^{63}$

While international laws which outlaw child marriage do infringe cultural rights, it is the argument of the 'child's best interests' that must prevail as the CRC directs that in all matters concerning children, the best interests of the child shall be the primary consideration. ${ }^{64}$ The CRC Committee has expressed the view that the 'best interests of the child' is a flexible, adaptable concept, and should be determined on a case-by-case basis. ${ }^{65}$

Some scholars, like Waschefort, are critical of the idea that children's capacity and interests should be determined on a casuistic basis. Waschefort writes: 66

International law cannot be based on a system whereby the unique development characteristics of each young person are considered to inform a determination as to whether or not the specific child can make an informed decision whether or not to enlist.

\footnotetext{
55 As above.

56 As above.

57 As above.

$58 \mathrm{M}$ Afkhami 'Cultural relativism and women's human rights' http:// www.mahnazafkhami.net/2000/cultural-relativism-and-womens-human-rights/ (accessed 28 September 2015).

59 As above.

60 As above.

61 As above.

62 As above.

63 See in this regard S Merry Human rights and gender violence: Translating international law into local justice (2006) 14-20.

64 Art 3(1).

65 General Comment 14 (2013) on the right of the child to have his or her best interests taken as a primary consideration (art 3 para 1) 9.

66 G Waschefort International law and child soldiers (2015) 11.
} 
Whereas Waschefort's argument makes practical sense, it fails to appreciate the fact that many domestic courts determine the culpability of children on a casuistic basis. The fact that domestic criminal justice systems differentiate on the basis of age does not mean that all children should be tarred with the same brush.

Child marriages have many harmful consequences, as discussed above, and, as a result, the child's best interests should limit any cultural rights. It is submitted that cultural considerations can only be accommodated if it can be proved that the child validly consented to entering into marriage or voluntarily became a child soldier. ${ }^{67}$ However, it is further submitted that consent given by children under seven years of age cannot be valid consent. This will be dealt with further in section 7 below.

\section{Child soldiers}

According to the Paris Principles and Guidelines, a child soldier is 'a child associated with an armed force or armed group ... [a child soldier] is any person below 18 years of age who is, or who has been, recruited or used by an armed force or armed group in any capacity'. This includes boys and girls used as fighters, messengers, porters, cooks and spies. Crucially, it includes girls and boys who are recruited for sexual purposes, such as sexual slavery. To meet the definition of a child soldier, therefore, it is not necessary for a child to be directly taking part in hostilities. ${ }^{68}$ Since the Paris Principles merely constitute soft law, domestic laws do not yet reflect this broader understanding of the definition of child soldiers. The approach taken in the Paris Principles, however, is a very positive and progressive development since it is a realistic reflection of the close relationship between child soldiering and child soldiers. Drumbl emphasises this shift in the understanding of child soldiering when he writes about the move towards referring not merely to child soldiers but to 'children associated with armed forces or armed groups' ${ }^{69}$

Children of both genders are used in armed conflict and play a wide variety of roles. These roles may involve frontline duties as fighters, but children may also be used in other roles such as porters, couriers, spies, guards, suicide bombers or human shields, or to perform domestic duties such as cooking and cleaning. ${ }^{70}$ Furthermore, armed groups could use both boys and girls for sexual purposes.

67 See in this regard L Mwambene \& J Sloth-Nielsen 'Benign accommodation? Ukuthwala, "forced marriage" and the South African Children's Act' (2011) 2 Journal of Family Law and Practice 5.

68 Paris Principles and Guidelines on Children Associated with Armed Forces or Armed Groups, 2007.

69 Drumbl (n 1 above) 4.

70 Drumbl (n 1 above). 
International standards do not prohibit the voluntary recruitment of children of 16 and 17 years by armed forces. However it certainly is contrary to best practice to recruit children of this age. ${ }^{71}$ The Optional Protocol on the Involvement of Children in Armed Conflict (OPAC) ${ }^{72}$ has set the minimum age for direct participation in hostilities and for compulsory recruitment by states' armed forces at 18 years. Even though states may, upon their ratification or accession to OPAC, accept volunteers from the age of 16 , states must deposit a binding declaration setting out their minimum age for voluntary recruitment and the safeguards employed for such recruitment. OPAC further prohibits both the use and recruitment of children under the age of 18 in hostilities by non-state armed groups.

Additional Protocol II to the Geneva Conventions puts the threshold as low as 15 years. This instrument states that ' $[c]$ hildren who have not attained the age of fifteen years shall neither be recruited in the armed forces or groups nor allowed to take part in hostilities'.$^{73}$

There is a need to determine the minimum age of criminal liability, internationally and nationally. This is becoming particularly important since children accused of committing crimes in the context of armed conflicts are being 'increasingly brought before the justice system, both international and national ... to stand trial as defendants'. ${ }^{74}$

\section{Juxtaposing and comparing child soldiering and child marriage}

At first glance, victims of child marriage and child soldiers appear to represent two sides of a coin: Victims of child marriage are typically considered victims and child soldiers are often considered perpetrators of crime. In international criminal law, the position of children in these two contexts is indeed very different. Without exception, victims of child marriage are always considered to be victims of the 'crime' of child marriage or forced marriage. Child soldiers, on the other hand, may be considered either perpetrators or victims or occasionally both. The prosecution by the International Criminal Court of a former Ugandan child soldier-turned-LRA commander, Domic Ongwen, has brought this matter to the public attention. ${ }^{75}$ However, some authors have rejected the binary victim/perpetrator distinction outright. ${ }^{76}$

71 Child Soldiers International http://www.child-soldiers.org/about_the_issues.php (accessed 20 September 2016).

72 Adopted by UN General Assembly on 25 May 2000, entered into force on 12 February 2002.

73 Art 4(3)(c).

74 UN Office of the Special Representative of the Secretary-General for Children in Armed Conflict Working Paper 3 (September 2011) 5.

75 M Schenkel 'Uganda: The thin line between victim and perpetrator' Mail \& Guardian 16 February 2015.

76 I Derluyn et al 'Vicitms and/or perpetrators? Towards an interdisciplinary dialogue on child soldiers' (2015) 15 BMC International Health and Human Rights 28. 
Others have described those in the position of Ongwen as 'complex political victims'. ${ }^{77}$ Whatever the prevailing view, as critiqued by Drumbl, children are passive victims. Child soldiers are almost always considered victims. ${ }^{78}$

A further overly simplistic distinction is prevalent in the literature and attitudes. A fairly superficial gender division is often drawn between children affected by child marriage and child soldiers. 'Victims' of child marriage are almost always perceived as female, whereas child soldiers are perceived to be male. Whereas the statistics confirm that this is indeed overwhelmingly the case, there are significant exceptions to this rule. In some countries, 40 per cent of armed force groups are made up of young girls. ${ }^{79}$ A prime example would be Uganda, where young girls account for a third of their child soldiers. ${ }^{80}$ Girls in these situations often become victims of the crime of forced pregnancy. ${ }^{81}$ The fact that female child soldiers are used not only as domestic servants, but also for sexual purposes, clearly illustrates the overlap and intersections between various forms of abuse and crimes against children.

Importantly, boys are also coerced into child marriage. The gender difference should, therefore, not lead one to support the idea that women should be protected whereas men should be more easily subjected to possible prosecution for child soldiering.

Children affected by child marriage and child soldiers suffer grave human rights violations. Forcing children to enter into marriage or to forcibly recruit children into the armed forces violates a wide range of fundamental human rights, such as the right to dignity, the right to education, the right to family life and the right to health. This means that child soldiers and children in child marriages often suffer the same type of harm.

Drumbl mentions the auxiliary activities to fighting in an armed conflict in which children take part. Recognising children who engage in these activities as child soldiers expands the category of child soldiers. Drumbl writes that, throughout history, '[children] have fought as soldiers; maintained morale as drummer boys; cooked, portered and sustained garrison life; served as defence of last resort; suffered indignities and abuses; and inspired through their courage ${ }^{\prime}{ }^{82}$

77 'Comparing victims and perpetrators in Uganda' JRP Field Note 75 http:// justiceandreconciliation.com/wp-content/uploads/2008/07/JRP_FN7_DominicOngwen.pdf (accessed 20 September 2016).

78 Interestingly, it may be argued that international criminal law has not been sufficiently sensitive to cases in which war criminals are prosecuted and where the defendant entered into the armed service as a child.

79 S Tiefenbrun 'Child soldiers, slavery and the trafficking of children' (2008) 31 Fordham International Law Journal 424.

80 It is well documented that girl soldiers suffer serious abuse. Tiefenbrun (n 79 above).

81 Tiefenbrun (n 79 above).

82 Drumbl (n 1 above) 27. 
This constitutes an important link between child marriage and child soldiering. Children in child marriages can also be considered child soldiers if they support the armed conflict in this way.

\section{Presence of duress}

It is often assumed that children who enter into the armed forces are victims of brainwashing. ${ }^{83} \mathrm{~A}$ widespread view exists that children who become soldiers are unduly influenced and indoctrinated and do not act voluntarily. Whereas it is indeed the case that children are often indoctrinated and forced into early marriage or child soldiering, it should be recognised that this is not always the case. We are of the view that one should treat the question of voluntariness with circumspection and resist the temptation of assuming that children do not voluntarily enter into marriages or enlist in the army. As stated above, it is emphasised that children under the age of seven do not have criminal capacity and do not have the ability to give genuine consent. However, the 'faultless and passive victim' image does not always fit the specific circumstances of child marriage or child soldiering. It should be recognised that older children possess various degrees of agency and autonomy. The paternalistic 'liberal' position, the ideology currently dominating the scholarship on child soldiering and child marriage, emphasises the victimhood of children and promotes the idea that children who have willingly taken part in hostilities are considered to have lost control of their limited agency. Agency is a type of autonomy which focuses not only on the capacity to conceive projects and values, but also the capacity to act upon them. ${ }^{84}$ Agency, as explained by Honwana, 'concerns events of which an individual is the perpetrator, in the sense that the individual could, at any phase in a given sequence of conduct, have acted differently'. ${ }^{85}$

In determining the possible culpability of children, the question of consent and the extent to which children have voluntarily entered into either early marriage or soldiering is highly relevant.

Consent has been defined as the 'legal competence and factual ability of the affected individual to dispose of the protected interest under attack' ${ }^{86}$ An individual may absolve a perpetrator from liability

83 See Tiefenbrun (n 79 above).

84 N Quenivet 'The liberal discourse and the new wars of/on children' (2013) 38 Brooklyn Journal of International Law 1104, citing D Johnston The idea of a liberal theory: A critique and reconstruction (1994) 71.

85 A Honwana 'Innocent and guilty: Child soldiers as interstitial and tactical agents' in A Honwana \& F de Boeck (eds) Makers and breakers: Children and youth in postcolonial Africa (2005) 31 48, quoting A Giddens The constitution of society (1984) 9. See also M Nussbaum \& R Dixon 'Children's rights and a capabilities approach: The question of special priority' (2012) 97 Cornell Law Review 549.

86 W Schomburg \& I Peterson 'Genuine consent to sexual violence in international criminal law' (2007) 101 American Journal of International Law 125. 
by giving genuine consent. ${ }^{87}$ The meaning of 'genuine consent' is, however, controversial in the context of child soldiers and child marriage. The ICTR in Gacumbitsi held that, where coercive factors can be proven, genuine consent is impossible. ${ }^{88}$

Child marriage is sometimes referred to as 'forced marriage' to emphasise the fact that young girls who are married are not in the position to give their full and free consent and are often coerced into marriage. ${ }^{89}$ Coercion in this sense would occur when children's parents or guardians put pressure on girls to get married, and sometimes even force them to. ${ }^{90}$ Of course, not only children are coerced into forced marriages, which is one reason why it is not accurate to describe all instances of child marriage as forced marriages.

Australia is one of the few jurisdictions that have explicitly criminalised coercion with respect to marriages. The amended Criminal Code ${ }^{91}$ states: $^{92}$

A marriage is a forced marriage if, because of the use of coercion, threat or deception, one party to the marriage (the victim) entered into the marriage without freely and fully consenting.

Coercion can include '(a) force; (b) duress; (c) detention; (d) psychological oppression; (e) abuse of power; and (f) taking advantage of a person's vulnerability'. ${ }^{93}$ This model is more than capable of being directly transferred and used to determine whether the marriage of a child was the result of coercion or in fact voluntary. In the event that coercion is present, the Criminal Code criminalises two types of conduct: first, the conduct of forcing a person to be party to a forced marriage; and, second, being a party to such a forced marriage but not the victim of or the one coerced into the forced marriage. 94

In addition to coercion, other factors, such as deception and emotional pressure, may also influence the genuineness of consent. The family and community constantly inform the child that the family's reputation is dependent on the marriage and, in extreme cases, the children are even isolated and ignored by their families. ${ }^{95}$

Whereas more often than not child marriages are entered into without the necessary consent, it should be appreciated that there will

\footnotetext{
87 As above.

88 Prosecutor v Gacumbitsi ICTR-2001-64-A para 321.

89 Plan International Australia Just married, just a child: Child marriage in the IndoPacific region (2015) 5.

90 As above.

91 Crimes Legislation Amendment Act $2013 \mathrm{sec}$ 270(7)(A).

92 Plan International (n 89 above) 30.

93 As above.

94 As above.

95 http://www.stopvaw.org/forced_and_child_marriage (accessed 16 September 2015).
} 
be marginal cases in which a girl has entered into a marriage of her own accord.

We support the argument that some children, more particularly young adolescents, do to a certain degree possess autonomy.

Adolescence has become a recognised developmental period in which there are differing levels of understanding and maturity. ${ }^{96}$ For example, 16 year-old children are better at reasoning than 13 yearolds. ${ }^{97}$ Drumbl's arguments for autonomy and international humanitarian norms allow the recruitment of soldiers from the age of 15 years. ${ }^{98}$ This article argues that, in certain circumstances, in cases where young adolescents are involved, it is possible that consent may be given freely without coercion of any kind.

Therefore, under the umbrella term of child marriage, a distinction should be made between early marriage and forced marriage. A forced marriage will be a marriage in which consent was not given or, where given, it was influenced by coercion and, therefore, cannot be considered true consent. The previous United Nations (UN) SecretaryGeneral, Kofi Annan, added that in its most extreme form, forced marriage can involve threatening behaviour, abduction, imprisonment, physical violence, rape and, in some cases, murder'. 99 Early marriage is a marriage in which a young adolescent has freely consented to the marriage.

This article proposes that, in the case of child marriages, the following presumptions should exist: Between the ages of zero and seven, it is irrebuttably presumed that genuine consent cannot be obtained from the child and, therefore, such a marriage is a forced marriage. Between the ages of seven and 15, children should be considered rebuttably incapable of giving consent. Between the ages of 15 and 18, it should be rebuttably presumed that genuine consent is capable of being given. This would correspond with the position in many domestic legal systems, such as South Africa and the United Kingdom. For those between 15 and 18, marriage can either be a forced marriage if no consent was given or, if consent was in fact given, it will merely be an early marriage.

In the context of an early marriage involving older children, one should consider the following question, namely, if the 'child' or 'young adolescent' wants to be in the marriage, should it still be considered unacceptable and a crime against humanity? Or is the issue of early marriage really only a problem when the marriage is abusive or violent?

96 N Cahn 'Poor children: Child "witches" and child soldiers in sub-Saharan Africa' (2005/6) 3 Ohio State Journal of Criminal Law 425.

97 As above.

98 Art 8(2) Rome Statute; art 38 CRC.

99 United Nations General Assembly 2012 'Report of the Special Rapporteur on Contemporary Forms of Slavery, including its Causes and Consequences' Gulnara Shahinian. Thematic report on servile marriage 10 July 2012. 
Multiple factors contribute to the prevalence of forced marriages. Marriage is seen as the penultimate protector of a girl's honour. 100 Marriage at a young age is considered to prevent premarital sex and to guard against sexual immorality. ${ }^{101}$ Forced marriage is also used to construct family alliances, create economic partnerships or strengthen political ties. ${ }^{102}$ Poverty is particularly crucial as an underlying factor leading to forced marriages. ${ }^{103} \mathrm{~A}$ girl is sometimes seen as an economic burden on her family, highlighting the importance of marriage, since the family will receive valuable goods and money from the groom in return for their daughter. ${ }^{104}$ Political instability and armed conflicts which impoverish communities are also contributing factors to forced marriages. 105

Forced marriages of young girls and women are prevalent in times of conflict and are sometimes called 'bush marriages' or even 'AK47 marriages'. 106 These girls and women are forcibly married to the men taking part in the armed hostilities, and are expected to guard the husband's property in addition to cooking, cleaning, satisfying his sexual desires and bearing his children. ${ }^{107}$ Forced marriages contain both sexual and non-sexual elements. The SCSL Appeals Chamber recognised forced marriage as a crime distinct from sexual slavery. ${ }^{108}$ It is important to recognise the non-sexual element of forced marriages, as the wives are not only sexually abused, but also subjected to other forms of abuse which must be taken into consideration. ${ }^{109}$ The Armed Forces Revolutionary Council (AFRC) Appeal Chamber also defined forced marriage as a crime against humanity. It added that it involved 'forced conjugal association with another person' ${ }^{110}$ Forced marriage as a crime against humanity was for the very first time recognised in international law by the SCSL. ${ }^{111}$

The crime of conscripting, enlisting and using child soldiers is often interlinked with the issue of forced marriage. ${ }^{112}$ In the case of the conflict in Sierra Leone, girls and women were abducted by child soldiers and were not only forced to marry them, but also to provide

100 'Child, early and forced marriage: A multi-country study' submission by Women Living Under Muslim Laws to OCHCR 13.

101 As above.

102 'Child, early and forced marriage' (n 100 above) 15.

103 'Child, early and forced marriage' 16.

104 As above.

105 'Child, early and forced marriage' (n 100 above) 17.

106 ASJ Park 'Forced marriage, girl soldiers and the Special Court for Sierra Leone' (2006) 15 Social and Legal Studies 327.

107 V Oosterveld 'The Special Court for Sierra Leone, child soldiers, and forced marriage: Providing clarity or confusion?' (2007) 45 The Canadian Yearbook of International Law 133.

108 As above.

109 Oosterveld (n 107 above) 155.

110 Oosterveld 133.

111 Oosterveld 152.

112 Oosterveld 169. 
support to those fighting in the front lines. ${ }^{113}$ These girls were then trained to burn down houses, spy on the enemy and loot. ${ }^{114}$ The UN Special Representative for the Secretary-General has expressed the view that the war crime of using child soldiers, in itself, can include subjecting women and children to forced marriage. ${ }^{115}$

The Rome Statute does not include forced marriage as a crime against humanity, neither does the Statute of the Special Court for Sierra Leone. The International Criminal Court can, therefore, be guided by the manner in which the SCSL treated the issue of forced marriage as a crime against humanity.

\section{Conclusion}

Although on the surface the position of children in early marriage and the position of child soldiers seem to be very different, there are important overlaps and commonalities between the positions of children in these circumstances. The article essentially argues that children, both in the context of child marriage and that of child soldiers, can possess a measure of agency and should not necessarily be considered innocent victims if they were at an age where they were capable of giving consent and did in fact give their consent freely and voluntarily. This position takes cultural arguments seriously without allowing culture to be used as a justification for harming children. Recognising this reality will help destigmatise the positions of older children, children on the verge of adulthood and young adults who decide to marry. It also recognises the reality that many older children willingly enter into marriage and soldiering and take advantage of or even benefit from the specific circumstances of marriage or the context of armed conflict. By advancing this argument, the authors do not deny the seriousness of the detrimental effects of marriage on young children or children who are the victims of forced marriage. The severely detrimental effects on children who are forcibly recruited into the armed forces are also recognised.

Tobin writes about children as 'vulnerable yet evolving in their autonomy'. ${ }^{116}$ The current international law position emphasises the vulnerability of children, but does not sufficiently appreciate the fact that children constantly evolve in their autonomy. Adopting presumptions used in the criminal law of domestic legal systems can assist in making the necessary distinctions within the category 'childhood'. This position may lead one to redefine concepts such as child soldiers and child marriage.

113 As above.

114 Park (n 106 above) 324.

115 Oosterveld (n 107 above) 169 fn 185.

116 Tobin (n 18 above) 10. 